\title{
Aproximação narrativa a Ex 3,1-6
}

\author{
Narrative Approach to Ex 3: 1-6
}

\section{Aproximación narrativa a Ex 3, 1-6}

\author{
Leonardo Agostini Fernandes*
}

\begin{abstract}
RESUMO
Ex 3,1-6 abre, para a história do antigo Israel, o ingresso de Moisés no misterioso desígnio salvífico de Deus, representado no fenômeno da sarça ardente e penetrado de sentido quanto ao lugar da revelação: "o solo é santo" (Ex 3,5). O protagonismo de Moisés não depende da sua capacidade de enfrentar o deserto ou da sua capacidade de querer descobrir o que está por detrás do mistério, mas na sua capacidade de ver, de ouvir e de responder a Deus com reverência, despojamento e assumir a missão. Este artigo avalia elementos da narrativa e se subdivide em quatro tópicos: contexto; texto; estrutura do texto; lógica da narrativa.

Palavras-chave: Análise narrativa; Livro do Êxodo; vocação; missão
\end{abstract}

\begin{abstract}
Ex 3:1-6 opens, for the history of ancient Israel, the ingress of Moses in the mysterious saving plan of God, represented in the phenomenon of the burning bush and penetrated with meaning as to the place of revelation: "the soil is holy" (Ex 3:5). Moses' role does not depend on his ability to face the desert or his ability to find out what lies behind the mystery, but on his ability to see, hear, and respond to God with reverence, carelessness, and taking on the mission. This paper evaluates elements of the narrative and is subdivided into four topics: context; text; text structure; narrative logic.

Keywords: Narrative analysis; Book of Exodus; vocation; mission.

\section{RESUMEN}

Ex 3,1-6 abre, para la historia del antiguo Israel, la entrada de Moisés en el misterioso plan de salvación de Dios, representado en el fenómeno de la zarza ardiente y penetrado con significado en cuanto al lugar de la revelación: "el suelo es santo" (Ex 3,5). El papel de Moisés no depende de su capacidad para enfrentar el desierto o de su capacidad para descubrir qué hay detrás del misterio, sino de su capacidad para ver, escuchar y responder a Dios con reverencia, descuido y asumir la misión. Este artículo evalúa elementos de la narrativa y se subdivide en cuatro partes: contexto; texto; estructura del texto; lógica narrativa. Palabras clave: Análisis narrativo; Libro del Éxodo; vocación; misión.
\end{abstract}

* Doutor em Teologia Bíblica pela PUG-Roma, Professor Adjunto 2 do Departamento de Teologia da PUC-Rio e professor de Sagradas Escrituras do Instituto Superior de Teologia da Arquidiocese do Rio de Janeiro. É membro da Associação Bíblica Brasileira (ABIB), da Associação Bíblica Italiana (ABI), da Sociedade de Teologia e Ciências da Religião (SOTER), da Society of Biblical Literature (SBL), e integra o grupo de pesquisa TIAT (Tradução e Interpretação do Antigo Testamento) junto ao CNPq. 


\section{Introdução}

Segundo a narrativa bíblica, transcorreram 80 anos entre o nascimento e o encontro de Moisés com Deus no Horeb (cf. Ex 2,1-4,17). Por que Deus esperou tanto tempo para se revelar a Moisés? Por que teve que esperar Moisés adentrar no deserto para atrair a sua atenção? Por que um monte, no deserto, foi escolhido para o momento do encontro de Moisés com Deus? Por acaso, a convivência com Jetro, seu sogro e sacerdote de Madiã, não teria proporcionado uma ocasião para a revelação acontecer? Será possível pensar que a revelação no deserto é melhor do que a revelação em um santuário, através de uma liturgia impecável?

Tudo o que aconteceu, porém, foi pura iniciativa divina, pois Moisés, pela narrativa, não provocou, não premeditou e não se preparou para esse encontro. Deus, que irrompe na história, foi inédito ao chamar Moisés e demonstrou que, para salvar o seu povo, quis contar com aquele no qual encontrara senso de justiça (cf. Ex 2,11-14).

Moisés, além de não ser conhecido do seu povo, viveu o drama de não saber quem era e para quem era. Deus, que irrompeu na sua vida, deu-lhe, pessoalmente, "a carteira de identidade", devolvendo-lhe o que havia descoberto em seu íntimo: o sentido da justiça capaz de carregar, sobre si, o sofrimento alheio. A conversão de rota aconteceu porque o ser humano Moisés foi encontrado pelo Deus pessoal, cuja referência é seu pai (cf. Ex 3,6). O que deveria ter sido um dia normal, na vida de um pastor, transformou-se em grande descoberta. Assim, o ponto de chegada de Moisés tornou-se o ponto de partida para Deus se revelar. O bem que Moisés procurou para o rebanho de Jetro, Deus procurou, por Moisés, para o seu povo.

A importância de Ex 3,1-4,18 resulta indiscutível, pelo lugar que ocupa na narrativa exodal e por seu conteúdo ser indispensável para a compreensão da manifestação de Deus e da sua decisão salvífica. A memória do êxodo foi conservada por várias tradições que, para além das próprias características e opções literárias e teológicas às vezes divergentes, foram amalgamadas para preservar a grandeza e a envergadura desse feito épico. "As tradições do êxodo estão redigidas a partir da experiência global da história de Israel, mais como profissões de fé do que como relatos acontecidos tal e qual" (VAZ, 2010, p. 228). Por isso, a cada episódio, o ouvinte-leitor pode perceber que Deus está na linha de frente para a realização do seu plano de salvação. 


\section{Contexto}

\section{Contextualização do episódio}

O Egito tinha acolhido o patriarca Jacó e os seus onze filhos, graças à boa fama de José (FERNANDES, 2014, p. 113-133) e aos favores do Faraó (cf. Gn 45,16-20; 47,5b-12), mas após um longo tempo de primavera, a terra promissora deixou de ser um local favorável para os filhos de Israel. ${ }^{1}$ Esta notícia é dada ao ouvinte-leitor, pelo narrador, com poucas palavras: "Levantou-se sobre Egito um novo rei, que não conhecia José" $($ Ex 1,8). A razão para essa mudança, pelo que se deduz da narrativa, foi de ordem demográfica e política (cf. Ex 1,9-10), mas foi também devido ao medo que derivou da visão distorcida que o Faraó teve da realidade (COSTACURTA, 2007, p. 192).

O novo rei do Egito, sequer mencionado por nome, assumiu três ações estratégicas: a) decidiu conter o número dos israelitas, por medo de que fizessem alianças com os inimigos (cf. Ex 1,9-10); b) determinou o trabalho forçado para mantê-los sob o peso de muito trabalho (cf. Ex 1,11-14); c) decretou o extermínio de todas as crianças do sexo masculino para reduzir a força varonil (cf. Ex 1,15-22).

A ação do Faraó, impondo-se pela força, revela a intenção de transferir para os filhos de Israel o próprio medo. Na medida em que aumenta a sua opressão esmagadora, sente que aumenta, em si mesmo, a própria angústia e pavor. É o poder condenado ao medo perene da sua auto-escravidão (OSTINELLI, 1996, p. 41-42). Estas medidas, porém, não surtiram o efeito desejado, pois graças a Deus, os filhos de Israel continuaram a ser ainda mais fecundos na terra que passou a oprimi-los (cf. Ex 1,20).

A notícia do crescimento demográfico dos israelitas tem a finalidade de mostrar que, além de ser um povo fecundo, cumpre-se nos filhos de Israel o primeiro preceito bíblico dado aos progenitores da espécie humana: "E Deus os abençoou; e Deus lhes disse: «Frutificai-vos, sede numerosos, enchei a terra, conquistai-a, e dominem o peixe do mar, o volátil dos céus e todo vivente do firmamento sobre a terra»" (Gn 1,28); ${ }^{2}$ bem como a renovação dessa ordem como bênção dada a Noé, depois que saiu da arca: "Frutificai-vos, sede numerosos, enchei a terra" (Gn 9,1).

\footnotetext{
1 Segundo uma tradição, os filhos de Israel permaneceram, no Egito, quatrocentos anos (cf. Gn 15,13; At 7,6), mas, segundo outra tradição, foram quatrocentos e trinta anos (cf. Ex 12,40-41).

2 Sobre o sentido do verbo $k a \bar{a} \underline{b} a s ̌$ e a sua interpretação no contexto do primeiro relato da criação, veja-se: FERNANDES, 2011, p. 27-46.
} 
Decretar a morte dos neonatos do sexo masculino significava, em primeiro lugar, uma ação contrária à bênção da procriação, e, em segundo lugar, uma ação insana, pois condenava a mão de obra israelita ao envelhecimento e, pouco a pouco, à sua extinção. A atitude do Faraó é pouco condizente com o desejo de ficar com os filhos de Israel no Egito, para continuar explorando-os como mão de obra, pois a força varonil devia ser a mais indicada e a mais importante para realizar os seus grandes projetos (cf. Ex 1,11-14).

Então, em um contexto de morte, decretada para todos os do sexo masculino, nasceu o futuro Moisés, de pai e mãe levitas (cf. Ex 2,1-2; $6,20)$. A sua mãe, através de um audacioso plano, procurou evitar o nefasto destino para o seu filho, mas, após três meses, vendo que não poderia ocultar a criança por mais tempo, colocou-a num cesto calafetado e depositou-o no rio. ${ }^{3} \mathrm{O}$ cesto foi acompanhado por sua irmã, que, pelo contexto, poderia fazer parte das criadas da filha do Faraó (cf. Ex 2,3-4). A razão desse plano é bem clara pelo que se segue: o cesto deveria ser encontrado pela filha do Faraó, que descera ao rio para se banhar. Para além dos detalhes oferecidos pelo texto, é possível pensar que a estratégia da mãe, na dinâmica da narrativa, poderia ter contado com as informações da irmã da criança a ser salva.

A filha do Faraó ordenou a uma de suas criadas para que pegasse o cesto. O menino, ainda sem nome, algo estranho para quem é filho de levitas, foi por ela retirado das águas e, ao vê-lo, logo se afeiçoou a ele. Apesar de reconhecer que a criança era um filho dos hebreus, deixou-o viver e, sem o saber, devolveu-o aos cuidados da própria mãe biológica, aceitando a sugestão da criada, irmã do menino. Após seu desmame, recebeu-o de volta, adotou-o com filho e lhe pôs o nome de Moisés (cf. Ex 2,5-10).

Esta breve narrativa apresenta Moisés sob uma prerrogativa que o coloca numa situação avantajada em relação ao restante do seu povo que sofria, duramente, com os trabalhos forçados. Moisés, apesar de seus privilégios, manifestou que tinha uma inclinação pelos mais fracos, desejava a justiça, mas aplicou-a com as suas próprias mãos. Por causa de um de seus irmãos de raça, cometeu um "assassinato involuntário", e diante de dois deles, que brigavam, sentiu medo pela recusa da ajuda que ofereceu

\footnotetext{
A descrição do cesto de papiro calafetado com betume e pez, dentro do qual a criança foi colocada a fim de ser salva, adéqua-se bem ao relato da ordem dada por Deus a Noé, para que construísse uma arca de madeira resinosa e caniços, calafetada com betume, a fim de salvar do dilúvio a sua família e as diferentes espécies de animais (cf. Gn 6,14). Sobre a figura de Moisés e a relação com figuras lendárias, veja-se: FERNANDES, 2016, p. 169-190).
} 
e por saber que o seu "crime" não ficara oculto. Viu-se, novamente, em perigo de morte e buscou salvar-se pela fuga para um local símbolo de morte: o deserto (cf. Ex 2,11-15).

De forma surpreendente e inesperada, uma nova situação de bem-estar aconteceu. Moisés colocou, novamente, o seu ímpeto de justiça a serviço de quem é fraco: jovens pastoras. Dessa vez, porém, foi recompensado por seu feito: recebeu uma delas como esposa: Séfora (cf. Ex 2,16-17), que inclusive, por ser proativa, irá salvá-lo da morte (FERNANDES, 2015, p. 59-84; GRENZER - SUZUKI, 2019, p. 1-20). Moisés foi acolhido com grande hospitalidade pelo seu futuro sogro e, em sua tenda, encontrou um lar, mulher, filhos e trabalho em Madiã. ${ }^{4}$

Deus irrompeu fortemente na vida de Moisés para desestabilizá-lo da sua segurança, que pelo contexto já durava uns quarenta anos, pois já tinha oitenta anos no momento em que foi comissionado para regressar ao Egito (cf. Ex 7,7). ${ }^{5}$ Criou-se, com isso, um interessante contraste entre os filhos de Israel, que estavam sofrendo no Egito, e Moisés que, escapando para salvar sua vida, se encontrava em Madiã, isto é, entre o Egito e Canaã. Ex 2,25 termina dizendo que "Deus viu os filhos de Israel e Deus conheceu" (em hebraico) ou "se lhes fez conhecido" (correção da LXX). Todavia, considerando Ex 3,7, pode-se concluir que a intenção era a de reforçar que Deus conhecia as angustias e a dura servidão do seu povo no Egito.

Assim, de acordo com o relato bíblico, o início da existência de Moisés foi muito conturbado, como conturbada, também, foi a missão que lhe foi confiada: voltar ao Egito, tirar o povo das mãos de Faraó e conduzir o povo liberto, mas de dura cerviz (cf. Ex 32,9; 33,3.5; 34,9), rumo ao Sinai, e deste para a terra prometida. Moisés, que já nascera condenado à morte, critério sine qua non que marca a sua existência, continuou vivendo

4 No Antigo Testamento, os madianitas são um povo nômade, que ocupava o golfo de Acabá, penetrando até o Sinai e ao Norte do território de Moab. Gn 37,28 os apresenta como comerciantes ismaelitas. A eles José foi vendido pelos seus irmãos, que por sua vez o venderam a Potifar, eunuco do Faraó e chefe dos cozinheiros (cf. Gn 37,36). Alguns elementos já podem ser colhidos deste fato. Os madianitas são descendentes de Abraão por meio de Cetura (cf. Gn 25,4) e possuem relações comerciais com o Egito. Com certa probabilidade, a Madiã bíblica pode ser identificada com a zona do Hejaz, a nordeste da Arábia Saudita, sobre as margens do Golfo de Aqaba (MAZZINGHI, 2012, p. 61-62).

5 A divisão dos anos de Moisés segue três etapas de quarenta anos cada uma: do nascimento à fuga do Egito, quarenta anos; da entrada na tenda de Jetro e regresso ao Egito, quarenta anos; enfim, da saída do Egito, conduzindo o povo pelo deserto até a sua morte no monte Nebo, mais quarenta anos. No total, Moisés vivera cento e vinte anos (cf. Dt 34,7), mais do que José, que morreu com a idade de cento e dez anos (cf. Gn 50,26), bem como do seu descendente Josué (cf. Js 24,29). 
ameaçado de morte, tanto pelos egípcios como pelo seu próprio povo. Uma notável relação se estabelece entre o início e o final da missão: Moisés, ao nascer, não tem direito a viver por decreto do Faraó e, no fim da vida, não tem direito a entrar e morrer na terra prometida por decreto de Deus.

Apesar de Moisés ter sido salvo "milagrosamente" e ter crescido no palácio, o livro do Êxodo não menciona nada sobre a sua infância e juventude. Moisés pertenceu, pelo sangue, ao povo hebreu, e, pela adoção, ao povo egípcio. Contudo, Moisés foi alguém que, ao entrar em cena, demonstrou ter um forte ímpeto de intolerância pela injustiça, por não ver a justiça e o direito praticados tanto por egípcios como por hebreus.

A contestação que Moisés recebeu ao intervir, quando viu dois hebreus litigando, antecipa a narrativa da objeção e da rejeição que se encontra em Ex 32,25-29. Moisés, continuamente, aparece contestado no seu "direito" de ser um juiz mediador, isto é, de penalizar o culpado nos casos de grave reato (cf. Ex 21,15-17; 22,17-18). Não obstante, age como juiz e defende a causa de Deus (cf. Ex 32,20; Dt 9,21 contém uma tradição diferente, pois Moisés não sentenciou o povo a beber o fruto do próprio pecado).

A vida de Moisés poderia ter sido concluída com os resultados de sua fuga, pois encontrou abrigo e constituiu família. A narrativa deste praticante da justiça, porém, não termina com uma próspera vida familiar. $\mathrm{Na}$ verdade, Ex 3,1 apresenta a experiência que desestabilizou Moisés e reacendeu, nele, o ímpeto libertador, fazendo dele a principal personagem do antigo Israel e o fundador de uma religião: o Javismo.

\section{Delimitação do texto}

O que é mencionado em Ex 2,11-22.23-25 pode ser considerado como uma etapa necessária do que é narrado em Ex 3,1-4,18. Por meio de uma sucessão de eventos, devidamente conexos entre si, o narrador conduz o ouvinte-leitor ${ }^{6}$ a perceber a razão para Moisés ter sido poupado da morte no início da vida e na sua maturidade.

6 O ouvinte-leitor não é um simples receptor do narrador. Ele é um verdadeiro interlocutor ou destinatário da narração. Os âmbitos mais propícios para o narrador realizar o seu papel na sociedade são: a família, a sinagoga e o culto. É preciso admitir que o "ouvinte-leitor real" é o público alvo do narrador e que pertencia à sua época. Ele, em primeiro lugar, deveria estar ambientado com o narrado ou nele deveria ser instruído. Contudo, o destinatário do livro, do ponto de vista literário, se torna "real" em qualquer época diante do conteúdo a ser transmitido. Sabedores de que este texto foi produzido por "hebreus" para "hebreus", eles e sua história se tornam necessários para que a narrativa alcance os seus objetivos e seja corretamente interpretada. 
Após saber que Moisés encontrou boa acolhida em Madiã, Ex 2,23-25 apresenta notícias que fazem o ouvinte-leitor "retornar" ao Egito, pois são oferecidas algumas informações importantes. Estas lançam as bases para todo o desenvolvimento posterior: a) o rei do Egito, sem dizer seu nome, está morto; b) os filhos de Israel gemem pela servidão e clamam sem que se diga a quem; d) este clamor sobe até Deus ('Elōhîm); e) Deus não ouve o clamor, mas os gemidos; f) Deus lembra-se da berit com os patriarcas; g) Deus viu os filhos de Israel; h) Deus conheceu.

Ex 2,23-25 é, na narrativa, uma interrupção necessária, pois serve para preencher um espaço temporal: da fuga do Egito até o encontro de Moisés com Deus no Horeb. São cerca de quarenta anos. Isto permite dizer que Ex 3,1 poderia ser a lógica continuação de Ex 2,22. Além disso, serve para dizer que a vocação e a missão Moisés, que consiste em retornar ao Egito, aconteceram em um tempo oportuno, pois já não havia mais o risco de morte para Moisés, resposta de Deus ao gemido e ao grito dos oprimidos.

Assim, o que precede Ex 3,1 funciona, do ponto de vista do relato, como uma ambientação adequada para o momento da revelação, pela qual YHWH se apresenta, chamando e comissionando Moisés para ser o libertador dos filhos de Israel.

A experiência que Moisés teve de Deus, no monte Horeb, subdivide-se em cinco cenas: $1^{\mathrm{a}}$ ) Ex 3,1-6; $2^{\mathrm{a}}$ ) Ex 3,7-15; $3^{\mathrm{a}}$ ) Ex 3,16-22; 4 $)$ Ex 4,1-9; $5^{\text {a) }}$ Ex 4,10-18. Nestas cinco cenas, a referência a Jetro abre (Ex 3,1) e fecha $($ Ex 4,18) o relato da experiência do Horeb, que está marcado por uma série de diálogos entre Moisés e YHWH.

Ex 3,1 é um novo episódio, em relação ao texto precedente, quer pela mudança de local, pois ocorre o deslocamento das notícias referentes ao Egito e a Madiã para o monte de Deus: o Horeb; quer pela teofania que abre uma nova fase na vida de Moisés. Esta novidade denota que Moisés deixou de ser alguém que adotara a vida seminômade, como pastor no lugar das filhas de Ragüel (cf. Ex 2,16-22), que nesta narrativa é chamado Jetro, para ser o futuro pastor do rebanho de YHWH: os filhos de Israel, que devem deixar o Egito e, por ele, serem conduzidos ao monte sagrado para selar a aliança por um culto sacrifical (cf. Ex 24,1-8).

Esta nova fase da vida de Moisés está marcada por uma construção gramatical que introduz uma nova cena dentro do que estava sendo narrado. O sujeito precede o verbo numa construção enfática (waw $+x+$ qatal), comum a muitos textos (cf. Gn 3,1; 4,1;16,1;21,1; 24,1;39,1), ressaltando a informação ou afirmação que abre um novo episódio. Outra mudança ocorre no ambiente e na atividade: da tenda de Jetro ao pastoreio cuidadoso com o seu rebanho deserto adentro até chegar ao Horeb. 
Ex 3,1-6 é a primeira cena e está centrada na revelação de Deus, segundo uma teofania, pela qual YHWH apresenta-se como o Deus da família de Moisés. A referência aos patriarcas em Ex 3,6 não possui o mesmo enfoque que Ex 2,24, mas não deixa de ser o precioso elo que une Moisés ao seu povo no Egito. A referência cultual e o nome "Deus" marcam o início e o fim desta cena. O principal elemento complicador encontra-se no uso de dois nomes distintos para a divindade: Deus e YHWH. ${ }^{7}$

Uma personagem importante, Moisés, a sua condição de vida familiar e um local determinado marcam o início do texto e introduzem os acontecimentos da experiência no Horeb (v. 1): a) A teofania se dá por um feito extraordinário (v. 2); b) A reação de quem, afetado por esse feito, quer conhecer o que estaria por detrás dele (v. 3); c) A contra-reação divina, mostrando que conhece a intenção de Moisés (v. 4); d) Esta intenção é deflagrada e vetada segundo critérios irrefutáveis (v. 5); e) A divindade se manifesta de forma a ser identificada e causa uma reação em Moisés (v. 6).

Assim, o texto é aberto com uma notícia sobre Moisés e com a referência à sua chegada "até o monte de Deus", e é fechado por uma reação de Moisés que esconde a face "porque temia dirigir o olhar para Deus".

Com relação ao texto subsequente, isto é, a segunda cena (cf. Ex 3,7-15), percebe-se uma mudança na atitude de Moisés que sai da prostração-temor para assumir sua parte no diálogo com Deus, pois acontece um avanço nessa nova cena através de YHWH que fala com Moisés. Em momento algum, se diz que Moisés levantou-se da sua prostração.

Uma distinta posição pode ser admitida na execução dos três sinais, contidos na quarta cena (cf. Ex 4,1-9), na execução da última ordem divina (cf. Ex 4,17) e na ação de retorno a Jetro (cf. Ex 4,18). O conteúdo da fala de Deus a Moisés apresenta o conhecimento que demonstrou ter sobre a situação dos filhos de Israel e o seu desejo de libertá-los da opressão do Egito, para conduzi-los a uma terra boa e fértil, justamente através da mediação de Moisés. Perceber, decifrar, entender e dialogar são quatro ações que marcam o desenvolvimento de Ex 3,1-6.

\footnotetext{
Ex 3,1-4,18 é um relato que foi elaborado a partir de diferentes tradições, denominadas, comumente, de "Elohista" e "Javista", devido à presença e fusão de dois nomes dados à divindade: El (Deus) e YHWH (Senhor). Sobre o percurso histórico e as problemáticas, que giram em torno do processo de formação do Pentateuco, ainda não se alcançou uma posição satisfatória, muitas questões permanecem abertas. Contudo, novas pesquisas avançam na direção e no aprofundamento do ressurgimento da hipótese dos fragmentos (GALVAGNO; GIUNTOLI, 2014, p. 145-215).
} 


\section{Texto}

$3^{1}$ E Moisés era quem apascentava o rebanho de Jetro, seu sogro, sacerdote de Madiã; e guiou o rebanho deserto adentro e chegou até o monte de Deus, o Horeb. ${ }^{2} \mathrm{E}$ apareceu-lhe um anjo de YHWH na chama de fogo, no meio da sarça; e eis que a sarça ardia no fogo, mas a sarça não era devorada. ${ }^{3}$ Então, disse Moisés: quero me desviar e verei esta grande visão, pois a sarça não se consome. ${ }^{4}$ Mas, YHWH viu que ele desviara para ver; então Deus o chamou, do meio da sarça, e disse: "Moisés, Moisés!" E ele respondeu: "Eis-me aqui!" ${ }^{5}$ E prosseguiu: "Não te aproximes até aqui; tira as tuas sandálias de teus pés, pois o lugar que tu estás de pé, sobre ele, é solo santo". ${ }^{6}$ E acrescentou: "Eu sou o Deus de teu pai, Deus de Abraão, Deus de Isaac e Deus de Jacó". Moisés ocultou a sua face, porque temia dirigir o olhar para Deus.

\section{Estrutura do texto}

A primeira cena, iniciada em Ex 3,1, com Moisés que avança deserto adentro e chega ao monte de Deus, termina em Ex 3,6, com Moisés que se prostra diante de Deus que se revela. O gesto de Moisés, que cobre o rosto, denota o impacto que o encontro causou. Pelo que vê e ouve, Moisés reconhece que está diante de algo inédito e muito acima das suas capacidades. O gesto de Moisés serve de pausa para as informações sucessivas, nas quais Deus se expressa a favor de Israel, que é citado, nominalmente, pela primeira vez neste texto, e porque todo o resto acontecerá em função dele.

Moisés, por ter entrado em um local sagrado, sem o saber, está diante do Deus de sua família e de seu povo. Deus fala a Moisés pelo vínculo que tem com o seu pai: um levita (cf. Ex 2,1), e com os patriarcas. O termo "pai” liga-se, perfeitamente, aos nomes que se seguem na divina apresentação que Deus faz de si a Moisés: “eu sou o Deus de teu pai, Deus de Abraão, Deus de Isaac e Deus de Jacó" (Ex 3,6).

Ex 3,1-6 é denominado, comumente, o episódio da "sarça ardente" e pode ser subdividido em três momentos de um passo introdutório no conjunto da teofania que fundamenta e ambienta a vocação e a missão de Moisés. Ao atrair a atenção de Moisés, a atenção do ouvinte-leitor é, igualmente, atraída para envolvê-lo e fazê-lo participante da experiência de fé mosaica.

vv. 1-2: O narrador localiza a cena, fala de Moisés, da iniciativa divina de se revelar, atraindo a atenção de Moisés;

vv. 3-5: Moisés monologa, pensa-reflete consigo mesmo; quer indagar a respeito do que vê. Deus/YHWH vê, fala e demonstra conhecer as intenções de Moisés;

vv. 6: Deus se auto-apresenta a Moisés, que se prostra acolhendo a fala divina. 
Ex 3,1-6 é um texto introdutório e pode ser visto como um quadro preparatório para toda a apresentação e o desdobramento dos fatos sucessivos na narrativa. A inédita experiência de Moisés no Horeb antecipa diversos dados, serve de prolepse que permite ao ouvinte-leitor receber e acompanhar as notícias que se seguirão numa direção sempre crescente (ALETTI, 2006, p. 80).

Por exemplo, a teofania que ocorreu diante de Moisés recapitulou a experiência do patriarca Abraão (cf. Gn 15,17-21) e antecipou a teofania que ocorreu diante do povo por ocasião da aliança do Sinai (cf. Ex 19). As ordens que Moisés recebeu para voltar ao Egito e tirar o povo da escravidão são sinais da presença e da justiça divina em ação. ${ }^{8}$ Estes sinais, que revestem a vocação e a missão de Moisés, contextualizam o Decálogo que fará do povo liberto uma nação eleita na busca e na pratica da justiça e do direito.

A voz do narrador, situando a fala de Moisés e de Deus, permite ao ouvinte-leitor se envolver na narrativa e a aderir aos argumentos nela apresentados. Ex 3,1-6, enquanto cena preparatória, diz respeito aos fundamentos da vocação e missão de Moisés, caracterizadas, centralizadas e dominadas pela experiência do "ver", do "ouvir" e do "responder", típico do diálogo, que domina todo o conjunto.

Não parece ser intenção do narrador, fazer entender que a descoberta deste lugar sagrado, por Moisés, seria suficiente para transformar o Horeb em um local de culto. No ciclo de Jacó, a santidade de Betel foi marcada como lugar de culto (cf. Gn 28,11-22). A diferença entre os dois relatos reside na forma como foram descobertos. Jacó pernoitou no local e, em sonho, YHWH se manifestou como Deus de Abraão e de Isaac. Moisés foi afetado em seus sentidos, visão e audição, pelos quais fez a sua experiência de YHWH em forma dialógica. É possível admitir uma aproximação dos dois relatos quer pelas tradições quer pela mão que as unificou ou, enfim, pela mão final do Pentateuco.

Se, por um lado, Moisés deve tirar as sandálias dos pés, por causa da sacralidade do local, por outro lado, ele esconde a face, por causa da teofania. Culto e presença divina não se separam e nem se excluem, mas se completam, no momento em que o objetivo do narrador foi o de ressaltar o que se passa na vida de quem entra na esfera do sagrado e se torna eleito para uma missão específica.

8 Resulta, tanto da análise histórica como bíblica, que os filhos de Israel, como imigrantes no Egito, foram obrigados à corveia, isto é, mão de obra a serviço do Estado, cujo representante divino era o Faraó que exigiu submissão e obediência. Ex 1,1-22; 2,23-25 confrontado com Ex 5,1-21 permite dizer que essas narrativas não retratam a mesma situação dos filhos de Israel (LOPASSO, 1999, p. 212-213). 
Js 5,13-15 muito se assemelha a Ex 3,1-6. Estes dois textos pertencem ao gênero literário da teofania em consonância com o gênero vocação do eleito. ${ }^{9}$ Com isso, marca-se a interação e a iniciativa entre Deus, que se revela, e o ser humano, que acolhe a revelação. ${ }^{10}$ Em ambos, encontram-se alguns pontos paralelos: a) personagens envolvidos: anjo de $\mathrm{YHWH}$, o eleito, e o próprio YHWH; b) o lugar da aparição; c) o reconhecimento humano da extraordinária presença divina; d) a instauração de um diálogo e a exigência de se tirar as sandálias devido à sacralidade do local.

Não é possível determinar a relação de dependência entre os dois textos. A índole narrativa, que objetiva justificar a futura ação do eleito, lança mão de um estilo e de um gênero literário que se adapta bem ao que fundamentará a escolha de um local para YHWH colocar o seu nome e a escolha-consagração de um povo para invocar este nome. Tanto Moisés como Josué foram eleitos e investidos de uma missão particular e num lugar particular pelo único e verdadeiro Deus que quer salvar o seu povo.

Moisés, porém, não recebeu apenas uma missão libertadora, mas foi investido como profeta, para comunicar ao Faraó a vontade de Deus. Para o antigo Israel, então, Moisés não foi só o libertador, mas o único profeta que se comunicava visualmente com Deus (cf. Nm 12,8; Dt 34,10-12). As figuras de libertador e de profeta são inseparáveis em Moisés, fazendo dele não só um modelo, mas alguém com um significado superior a todos os demais libertadores e profetas que o antigo Israel conheceu e registrou na sua história (KESSLER, 2013, p. 350).

\section{A lógica da narrativa}

Quanto ao tempo, a primeira cena não apresenta uma marca temporal definida. Não há alguma menção se o fato ocorreu durante o dia ou

9 Existem outros exemplos de teofania que incluem a vocação e missão de pessoas que atuam, segundo os ditames divinos, para operar a salvação do povo eleito. Jz 6,11-12 descreve uma aparição do anjo de YHWH a Gedeão, comunicando-lhe a vontade divina para que liberte o povo através de suas mãos. Is 6,1-6 contextualiza a vocação e a missão de Isaías no âmbito cultual. Ez 1,4-28 não alude, diretamente, à vocação e à missão de Ezequiel, mas à visão do carro de YHWH leva o profeta a se prostrar por terra, reconhecendo que está diante do próprio Deus. Nestes casos, a experiência da teofania é visual.

${ }_{10}$ Gn 46,1-7 relata a transferência de Jacó e sua família para o Egito. Este breve episódio também possui pontos de contato com Ex 3,1-6. Em ambos os casos, há um ambiente cultual, pelo qual Deus fala, se manifesta próximo ao eleito, que responde "Eis-me aqui" e o convence a ir para o Egito. No caso de Jacó, para se instalar, com a promessa da assistência divina e do futuro regresso. No caso de Moisés, para desinstalar os descendentes de Jacó e fazer cumprir a promessa de regresso (DOZEMAN, 2009, p. 121). 
à noite. A pessoal experiência de Deus, Moisés a teve no tempo do seu serviço a Jetro como pastor do seu rebanho e esposo de Séfora. Pelo contexto imediato, não se sabe a idade que Moisés tinha, quando recebeu o seu chamado e missão. Ex 7,7 afirma que Moisés tinha oitenta anos que, segundo a mentalidade antiga, representava duas gerações, e morrerá com cento e vinte anos, alcançando três gerações (cf. Dt 34,7).

Quanto ao lugar, encontra-se uma clara referência quanto a Jetro: "sacerdote de Madiã", e quanto ao pastoreio de Moisés que conduziu o rebanho "deserto adentro e chegou até o monte de Deus, o Horeb" (Ex $3,1)$. Este local recebe, do próprio Deus que se revela, uma especificação religiosa profunda e marcante: “o lugar que tu estás de pé, sobre ele, é solo santo" (Ex 3,5).

Quanto às personagens, elas podem ser classificadas em diretas e indiretas. O narrador (vv. 1-3a.4a.4c.5a.6a.6d); Moisés (vv. 3b.4d); o anjo de YHWH (v. 2a), Deus-YHWH (3,4b.5b.6b) são as personagens diretas. Jetro, citado duas vezes (v. 1), e que, no final, entra em cena como sujeito de uma fala (Ex 4,18c); o "pai" de Moisés (v. 6b), e os patriarcas Abraão, Isaac e Jacó (v. 6c) são as personagens indiretas. O ouvinte-leitor, ao mesmo tempo em que é conduzido pelo narrador, é, também, favorecido pelas ações e experiências das personagens. Sobre o plano da narrativa, o ouvinte-leitor sabe muito mais do que as personagens que atuam em cada cena, pois recebe notícias antecipadas.

Quanto ao tema, a centralidade recai sobre a manifestação de Deus a Moisés, na qual se apresenta como próximo e familiar: "Eu sou o Deus de teu pai, Deus de Abraão, Deus de Isaac e Deus de Jacó" (Ex 3,6). A revelação divina acontece envolvendo Moisés, atraído pelo fenômeno que se descortinou diante dos seus olhos. O desejo de Deus se revelar encontra-se com o desejo de Moisés se certificar quanto ao fato da sarça arder no fogo e não ser consumida por ele.

Quanto ao conteúdo das falas, o narrador: a) introduz algumas notícias sobre Moisés: é pastor do rebanho de seu sogro, Jetro que é sacerdote de Madiã; parece conhecer o deserto; não percebe a aparição do anjo de YHWH, ele só vê a sarça que arde e não se consome (cf. Ex 3,1-2); b) introduz o monólogo de Moisés (v. 3a) e faz o ouvinte-leitor perceber que YHWH está atento à intenção de Moisés; não é o anjo quem interpela Moisés, mas é Deus (v. 4c); c) introduz a réplica de Moisés $(3,4 \mathrm{c})$; d) introduz a nova fala de Deus (v. 5a) e a complementação desta fala (v. 6a); d) por último, revela que Moisés assumiu uma atitude reverente (v. 6c). 
Moisés entra em cena atento ao fenômeno, desejoso de conhecer (v. $3 \mathrm{~b}$ ) e responde à voz desconhecida (v. 4b); Deus chama Moisés pelo nome (v. 4b); mas não permite que Moisés se aproxime, revelando a qualidade do lugar sobre o qual ele está pisando (v. 5b); revela-se próximo e familiar, mas de modo solene (v. 6).

Quanto ao narrador, embora seja uma voz anônima, é quem conduz todo o relato. Deve ser apreciado como uma voz importante, pois toda a "história" está sendo transmitida através dele e por suas habilidades para o ouvinte-leitor. Ele age no texto como se fosse o diretor de um filme, fazendo entrar em cena cada personagem no seu devido tempo. A trama narrada, de certa forma, está debaixo do domínio do narrador que a conduz e mostra a sua evolução, pois é responsável pelas antecipações, progressões, digressões e evoluções que acontecem na dinâmica da narrativa.

O narrador domina uma arte, cujo principal objetivo é oferecer ao ouvinte-leitor a possibilidade de descobrir, pelo fio condutor ou trama, como os acontecimentos estão sendo tecidos. Ele quer envolver e tornar o ouvinte-leitor um interlocutor ativo na narrativa, não deixando que fique na passividade ou apenas como espectador. No seu modo de narrar e com os elementos utilizados, o narrador quer provocar os sentimentos, as emoções e a reflexão do seu interlocutor. Isto revitaliza o que está sendo narrado, proporcionando, de fato, uma "reinterpretação" ou uma "atualização" do conteúdo e dos seus objetivos. Com isso, o narrador coloca o ouvinte-leitor face a face com as personagens, em particular com Deus, e é envolvido nas situações narradas.

Criar uma identificação com as personagens, que estão agindo na história, é um modo de interagir com o interlocutor. Se esta interação acontece, o narrado não é mais algo do passado, mas uma palavra que revive na história de quem ouve ou lê. Todavia, o interlocutor está nas mãos do narrador, pois cada personagem e as ações dependem dele. Nisto consiste a autoridade que foi dada ao narrador para conduzir o interlocutor a tomar posição diante do texto e das realidades nele presentes.

O narrador é uma personagem de fé. Do ponto de vista da sua vocação e missão, está a favor da revelação e do plano divino para o ser humano. O narrador assume, assim, um papel de mediador entre Deus e os interlocutores que são, no fundo, os atores reais e ideais da história que está narrando. Além disso, alguns movimentos são, claramente, percebidos no texto:

Movimento relacional: Moisés é pastor para Jetro que é sogro de Moisés. 
Movimento espacial: de Madiã, lugar onde reside Moisés com sua família, ao Horeb, monte santo, onde Deus reside.

Movimento fenomenológico: aparece o anjo de YHWH, mas a sarça é o que Moisés vê e tem admiração, pois ela não se consome no fogo. A voz divina ouvida e entendida por Moisés é, igualmente, um fenômeno no texto. Ver e ouvir são dois níveis básicos para se estabelecer uma comunicação interpessoal.

Movimento interno-externo: de um lado, Moisés "diz consigo mesmo" o seu projeto de ver o que está acontecendo; de outro lado, Deus que impede tal desejo. É uma primeira frustração para Moisés, que antecipa a mais dura negação de Deus em sua vida: não entrará na terra prometida (cf. Nm 20,12-13).

Movimento dialógico: Moisés quer se aproximar para ver-conhecer o fenômeno, mas é Deus quem se aproxima dialogando com ele, revelando-se como quem conhece Moisés pessoalmente, pois o chama pelo nome. A resposta ao chamado é dada, "Eis-me aqui!", mostrando que Moisés conseguiu ouvir e entender o conteúdo da voz. Nisso, o diálogo com Deus se estabelece.

Os estágios da narrativa, introdução, ação, reação, complicação, climax e desfecho, podem ser percebidos com clareza. "E Moisés era quem apascentava o rebanho de Jetro, seu sogro, sacerdote de Madiã; e guiou o rebanho deserto adentro e chegou até o monte de Deus, o Horeb" (v. 1: introdução); "E apareceu-lhe um anjo de YHWH na chama de fogo, no meio da sarça; e eis que a sarça ardia no fogo, mas a sarça não era devorada" (v. 2: ação); "Então, disse Moisés: quero me desviar e verei esta grande visão, pois a sarça não se consome. Mas YHWH viu que ele se desviara para ver; então Deus o chamou, do meio da sarça, e disse: “Moisés, Moisés!” E ele respondeu: "Eis-me aqui!" (vv. 3-4: reação) ${ }^{5} \mathrm{E}$ prosseguiu: "Não te aproximes até aqui; tira as tuas sandálias de teus pés, pois o lugar que tu estás de pé, sobre ele, é solo santo." (v. 5: complicação); "E acrescentou: "Eu sou o Deus de teu pai, Deus de Abraão, Deus de Isaac e Deus de Jacó" (v. 6a: clímax); "Moisés ocultou a sua face, porque temia dirigir o olhar para Deus" (v. 6b: desfecho).

\section{Considerações finais}

Ex 3,1-6 é uma narrativa que fundamenta, com base em uma experiência, a vocação e a missão de Moisés como o eleito libertador. Pela forma como Deus se manifestou a Moisés, o narrador prepara o ouvinte-leitor 
para descobrir a incapacidade de Moisés, e de cada eleito, de resistir à manifestação divina e aos seus planos. As objeções que se seguirão, em forma de diálogos (cf. Ex 3,7-4,18), tendem a incrementar ainda mais a natureza da difícil missão libertadora.

A vocação e o dom da missão para Moisés aconteceram, exatamente, no momento em que ele estava ocupado com o rebanho do seu sogro Jetro. Em outras palavras, Moisés foi alcançado por Deus no momento em que desempenhava a função que lhe caberá como libertador e condutor do povo eleito, fazendo-o sair do Egito, caminhar e sobreviver às duras penas do deserto.

Na manifestação de Deus a Moisés, percebe-se a sua sutil inclusão no importante contexto dos grandes antepassados do povo eleito. No vínculo da fé familiar, Moisés pode reconhecer sua própria identidade religiosa e permitir que o fogo da paixão pela justiça volte a ser utilizado pelo bem do seu povo (STANCARI, 1987, p. 28).

Se, por um lado, a vocação e a missão de Abraão antecedem, literariamente, a vocação e missão de Moisés; por outro lado, do ponto de vista antropológico, a de Moisés contextualiza melhor não só a grandeza do dom divino, mas enfatiza o quanto o ser humano é capaz de resistir ao chamado e às implicações que dele derivam. Isto foi feito no momento em que Moisés disse "Eis-me aqui!" e Deus revelou quem lhe falava.

Os vários elementos que colocaram Moisés diante da teofania, também os estenderam para o ouvinte-leitor, ajudando a perceber que a sarça, que arde sem se consumir, serviu para ambientá-lo diante da experiência que Moisés fez de Deus, ao ouvir que ele estava diante do Deus de sua família ligada aos patriarcas.

O ouvinte-leitor é envolvido na narrativa, é chamado a participar desta revelação e a descobrir que "temer" a Deus é o primeiro passo para se vencer o "medo" diante da missão e dos seus obstáculos. O temor de Deus é gerador de comunhão, ao passo que o medo é gerador de divisão.

O encontro com o transcendente revela-se inexplicável e incontrolável. Diante da grandeza de Deus, o ser humano, com Moisés, pode tomar consciência de que a sua pequenez não é uma desvantagem, mas a condição indispensável para que, no temor, a fragilidade que o eleito experimenta seja sinal da eficácia de Deus. Este escolhe se revelar através de meios não convencionais, porque são envolventes e comunicadores de vida e de comunhão.

A experiência de Moisés foi elaborada para se tornar paradigmática. No antigo Israel, diversos personagens, que receberam uma vocação e missão, experimentaram o positivo efeito que o temor de Deus é capaz de 
produzir. Assim, cada ser humano, diante de Deus, que chama e comissiona para participar de seu projeto salvífico, tem a chance de responder e de se envolver pessoalmente nesse projeto.

No nosso tempo, como no passado, Deus continua tomando a iniciativa de se fazer visível e audível de diferentes modos. Para ver e ouvir Deus é preciso esvaziar-se das próprias pretensões e abrir-se para o impossível acontecer na possibilidade de cada dia.

\section{Referências bibliográficas}

ALETTI, Jean-Noël et alii. Lessico ragionato dell'esegesi biblica. Le parole, gli approcci, gli autori. Brescia: Queriniana, 2006.

ALONSO SCHÖKEL, Luis. Dicionário bíblico hebraico-português. São Paulo: Paulus, 1997. COSTACURTA, Bruna. La vita minacciata. Il tema della paura nella Bibbia ebraica. Roma: PIB, 2007.

DOZEMAN, Thomas B. Commentary on Exodus. Michigan: Grand Rapids, 2009.

FERNANDES, Leonardo Agostini. Onde estiver a Torá, estará meu servo Moisés. In: CARNEIRO, M.S.; OTTERMAN, M.; FIGUEIREDO, T.J.A. (Orgs.). Pentateuco: da formação à recepção. São Paulo: Paulinas, 2016, p. 169-190.

FERNANDES, Leonardo Agostini. Por que morreremos na tua presença?: uma análise de Gn 47,13-26. Perspectiva Teológica, Belo Horizonte, n. 46, p. 113-133, 2014.

FERNANDES, Leonardo Agostini. Séfora: a mulher proativa que livra o homem da morte (Ex 4,24-26). Revista de Cultura Teológica, São Paulo, n. 86, p. 59-84, 2015.

FERNANDES, Leonardo Agostini. Teologia, antropologia e ecologia em Gn 1,1-2,4a. Atualidade Teológica, Rio de Janeiro, n. 37, p. 27-46, 2011.

GALVAGNO, Germano; GIUNTOLI, Federico. Dai frammenti alla storia. Introduzione al Pentateuco. Torino: ELLEDICI, 2014.

GRENZER, Matthias; SUZUKI, Francisca C.C. Em defesa de seu esposo: o protagonismo de Séfora em Ex 4,24-26. Theologica Xaveriana, Bogotá, n. 187, p. 1-20, 2019.

KESSLER, Rainer. Vocación para la libertad: el caso Moisés. Pistis \& Praxis, Curitiba, n. 5/2, p. 345-363, 2013.

LOPASSO, Vincenzo. La conoscenza di YHWH in Es 1-15 alla luce dell'ambiente egiziano. Bibbia e Oriente, Roma, n. 41, p. 204-224, 1999.

MAZZINGHI, Luca. Madian. In: Il libro dell'Esodo (A cura di Pier Luigi Ferrari). Padova: Edizioni Messaggero, 2012.

OSTINELLI, Caterina. Tra paura e timore nell'Esodo. Parola, Spirito e Vita, Bologna, n. 33, p. 39-53, 1996.

VAZ, Armindo dos Santos. Força hermenêutica do Êxodo de Israel. Itinerarium, Portugal, n. 56, p. 225-233, 2010.

Submetido em: 29-8-2019

Aceito em: 10-10-2019 